\title{
Environment-friendly clay coagulant aid for wastewater treatment
}

\author{
Sharmin Sultana ${ }^{1} \cdot$ Boloram Karmaker $^{1} \cdot$ A. S. M. Saifullah ${ }^{1} \cdot$ Md. Galal Uddin $^{2} \cdot$ Md. Moniruzzaman $^{3}$
}

Received: 6 November 2020 / Accepted: 15 November 2021 / Published online: 30 November 2021

(c) The Author(s) 2021

\begin{abstract}
Wastewater management and its environment-friendly applications seem to be very complicated associated with chemical effects due to their dynamic characteristics for developing countries. Most of the world's agencies or countries have been treated wastewater using chemical coagulants which have contributed to other environmental complications. Considering the impacts of chemical coagulation, this study is novel research to identify alternative components that would be applied as a natural coagulant. The present study was conducted using two different regional clays as coagulants which were collected from Portugal and Bangladesh's Patuakhali coastal area. The clay coagulant applications were applied to investigate the removal efficiency of physical properties (turbidity), chemical properties ( $\mathrm{pH}$ and $\mathrm{COD}$ ), and heavy metals $(\mathrm{Cr}, \mathrm{Cd}, \mathrm{Ni}$, and $\mathrm{Pb}$ ) from wastewater. Comparatively, the highest removal efficiency was examined by the coastal clay of Patuakhali. This soil is also easily available in the local context and can be economically viable.
\end{abstract}

Keyword Wastewater treatment $\cdot$ Natural coagulant $\cdot$ Turbidity removal $\cdot$ COD reduction

\section{Introduction}

Water is an invaluable shared resource with considerable social, cultural, environmental, and economic worth. The rapid growth of the population around the world is associated with using huge quantities of water in different activities including the industrial, agricultural, and household activities (Mohamed et al. 2017). Those activities generate a contaminated wastewater with the chemical and biological residues. Industrial use of water accounts for around one-quarter of worldwide freshwater demand (Judd 1999). About 900 polluting industries in Bangladesh dispose off untreated industrial wastes directly into rivers (DPCD 2003). The wastewaters mainly comprise chemicals like hydrosulfite, sulfide, and sulfur dyes, causing rapid depletion of

\section{A. S. M. Saifullah \\ saifullahasm@yahoo.com}

1 Department of Environmental Science and Resource Management, Mawlana Bhashani Science and Technology University, Tangail 1902, Bangladesh

2 Department of Civil Engineering, College of Science and Engineering, National University of Ireland, Galway, Ireland

3 Bangladesh Reference Institution for Chemical Measurements (BRiCM), Dr. Qudrat-e- Khuda Road, Dhanmondi, Dhaka 1205, Bangladesh dissolved oxygen, affecting aquatic life adversely (Husain et al. 2013). Therefore, reactive effluents from dying industries create specific chemical hazards and produce several environmental problems (Riera-Torres et al. 2010; Verma et al. 2012). The effluents discharged from textile and dyeing industries may cause alteration of the physical, chemical, and biological properties of the aquatic environment by a continuous change in temperature, odor, noise, turbidity, etc., that is harmful to public health, livestock, wildlife, fish, and another biodiversity (Sultana et al. 2009). Aluminum found in discharged effluents is a major poisoning factor in encephalopathy dialysis and contributes to Alzheimer's disease (Yarahmadi et al. 2009). Polyaluminum chloride (PAC) and alum $\left(\mathrm{AlCl}_{3}\right)$ add impurities such as epichloride, which is carcinogenic.

Clay minerals have high cationic exchangeable capacity existing as a natural substance that is used for water treatment and materials absorbance and have other catalysis properties besides low cost and availability (Ingram et al., 2003). It was reported that clay minerals have been used as a coagulant aid removal of toxic compounds, pesticide, herbicide, heavy metals, and color removal (Hascakir et al. 2008). Clay is composed of particles smaller than $2 \mu$, which places them within the limit of the colloidal state (Gillott 1968). Owing to their interesting physicochemical properties (lamellar structure, high surface area) 
clay minerals have great potential to fix pollutants, such as heavy metals and organic compounds (Hajjaji et al. 2001), Wu et al. (1999), Laird and Fleming (1999), Viraraghavan and Kapoor (1994), Schutless and Huang (1990) Sharma et al. (1990), and Cadena et al. (1990) have all used clays in batch adsorption experiments for pollutant attenuation in aqueous media. Research findings showed that clays have high potential in water and wastewater treatment. Clay minerals have a high cationic exchangeable capacity that exists as a natural substance used for water treatment and materials absorbance. They also have other catalytic properties besides low cost and availability (Ingram et al. 2003). It was reported that clay minerals had been used as a coagulant aid for removal of toxic compounds, pesticide, herbicide, heavy metals, and color (Hascakir et al. 2008). The use of clay mineral has undoubtedly become more popular and widely used as an adsorbent and ion exchange for water and wastewater treatment applications specially for removing heavy metals, organic pollutants, and nutrients (Abdelaal 2004). In Bangladesh, treating industrial wastewater is a great challenge due to the high cost of chemical coagulants (Awad et al. 2013) and their side effects. Therefore, the current study deals with natural clay coagulants' technical feasibility for the treatment and improvement of wastewater before the final disposal into the environment. The researchers' main objectives are to develop clay-based coagulant aid for effluent treatment plant (ETP) and characterize the developed coagulants.

\section{Materials and methods}

\section{Sampling stations}

Clay samples for coagulants were collected from Patuakhali, a coastal area of Bangladesh (Fig. 1a, b) and from Portugal (Fig. 1c). Wastewater samples were collected from different textile industries in Gazipur, Bangladesh.

\section{Sample collection and preparation}

\section{Wastewater sample collection}

Wastewater samples were collected from five textile industries of Gazipur district, Bangladesh, following the sampling techniques as outlined by APHA (1995). The effluent samples were collected in $500-\mathrm{mL}$ plastic bottles from every selected industry to analyze $\mathrm{pH}$, turbidity, COD, and heavy metals. Before sample collection, all the bottles were washed with tap water followed by distilled water. Sampling followed the sampling techniques as outlined by APHA (1995).

\section{Soil sample collection}

Two soil samples were collected from two stations of Hazipara under Kolapara thana in Patuakhali, Bangladesh, and one from Portugal. Samples were collected in zip lock bags. After collection, the samples were carefully carried to the laboratory and from the samples, the gravels, pebbles, plant roots; leaves, etc., were separated. The samples were dried in air for 15 days by spreading on a clean piece of polythene bags. The dried samples were mortared to a fine powder and passed through a plastic sieve of $0.3 \mathrm{~mm}$ diameter and preserved in aluminum foil paper for laboratory analysis.

\section{Optimization of coagulant dosage}

In the initial stage of the study, the efficiency of the coagulants was tested in terms of the reduction of turbidity. The results from this stage of study encouraged to proceed further to the second stage, with the coagulant dosage optimized at 1, 1.5, 2, and $2.5 \mathrm{~g} / \mathrm{L}$. American Water Works Agency (AWWA) 5220D (Closed Reflux, Colorimetric Method) was used for dosage optimization. $1.5 \mathrm{~g} / \mathrm{L}$ dose was selected for Patuakhali soil, and $2.5 \mathrm{~g} / \mathrm{L}$ dose was selected for soil Portugal.

\section{Optimization of $\mathrm{pH}$}

The optimum value of $\mathrm{pH}$ depends essentially on the properties of the water treated, type of coagulant used and its concentration. Usually, after the addition of different coagulants, the $\mathrm{pH}$ of the treated wastewater decreased from 5.81 to 7.03 (Sanchez et al. 2012). Following the determination of the optimum dosage of the coagulants, $\mathrm{pH}$ test was carried out to determine the optimum range of the $\mathrm{pH}$ value, which gives the highest turbidity removal. Hydrochloric acid $(\mathrm{HCl})$ $0.1 \mathrm{M}$ and sodium hydroxide $(\mathrm{NaOH}) 0.1 \mathrm{M}$ were used for adjusting the $\mathrm{pH}$ at the desired levels $(2,4,6,8)$.

\section{Optimization of temperature and contact time}

The temperature for the thermo-reactor was optimized at $150^{\circ} \mathrm{C}$, and the contact time was $1 \mathrm{~h}$ and $45 \mathrm{~min}$.

\section{Volume optimization}

According to AWWA 5220D method, $212.5 \mathrm{mg}$ potassium hydrogen phthalate with $500 \mathrm{ml}$ DI water (500 ppm COD) was taken in a volumetric flask. From this solution $50 \mathrm{ml}, 100 \mathrm{ml}$, $150 \mathrm{ml}$, and $200 \mathrm{ml}$ were taken in four conical flasks and soil samples were added in each. Then, these flasks were placed on the shaker and filtered by syringe filter paper. After that $2.5 \mathrm{ml}$ soil samples, $1.5 \mathrm{ml}$ digestion solution and $3.5 \mathrm{ml}$ sulfuric acid solution were received in vials and placed those in a 


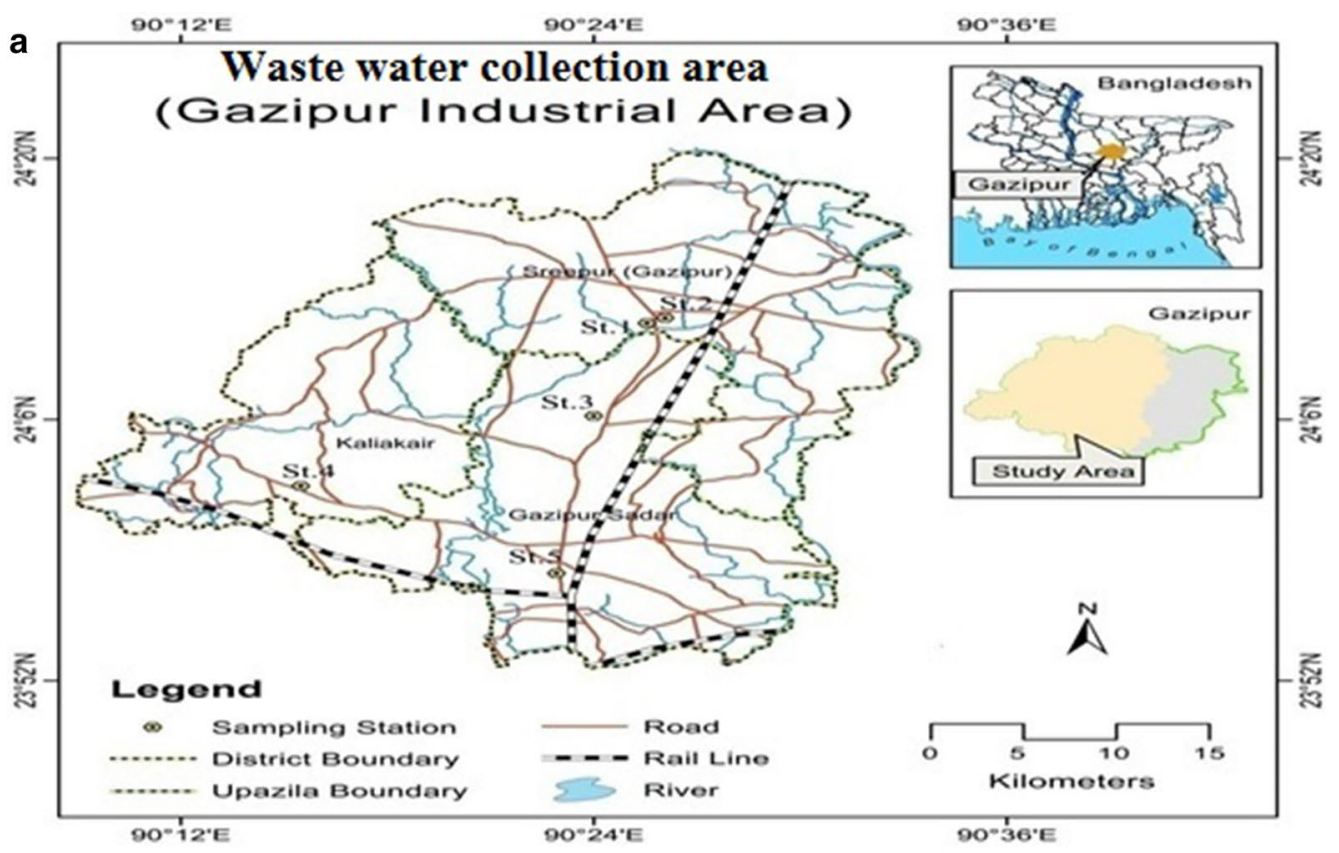

b $90^{*} 10 \mathrm{E}$ sorist

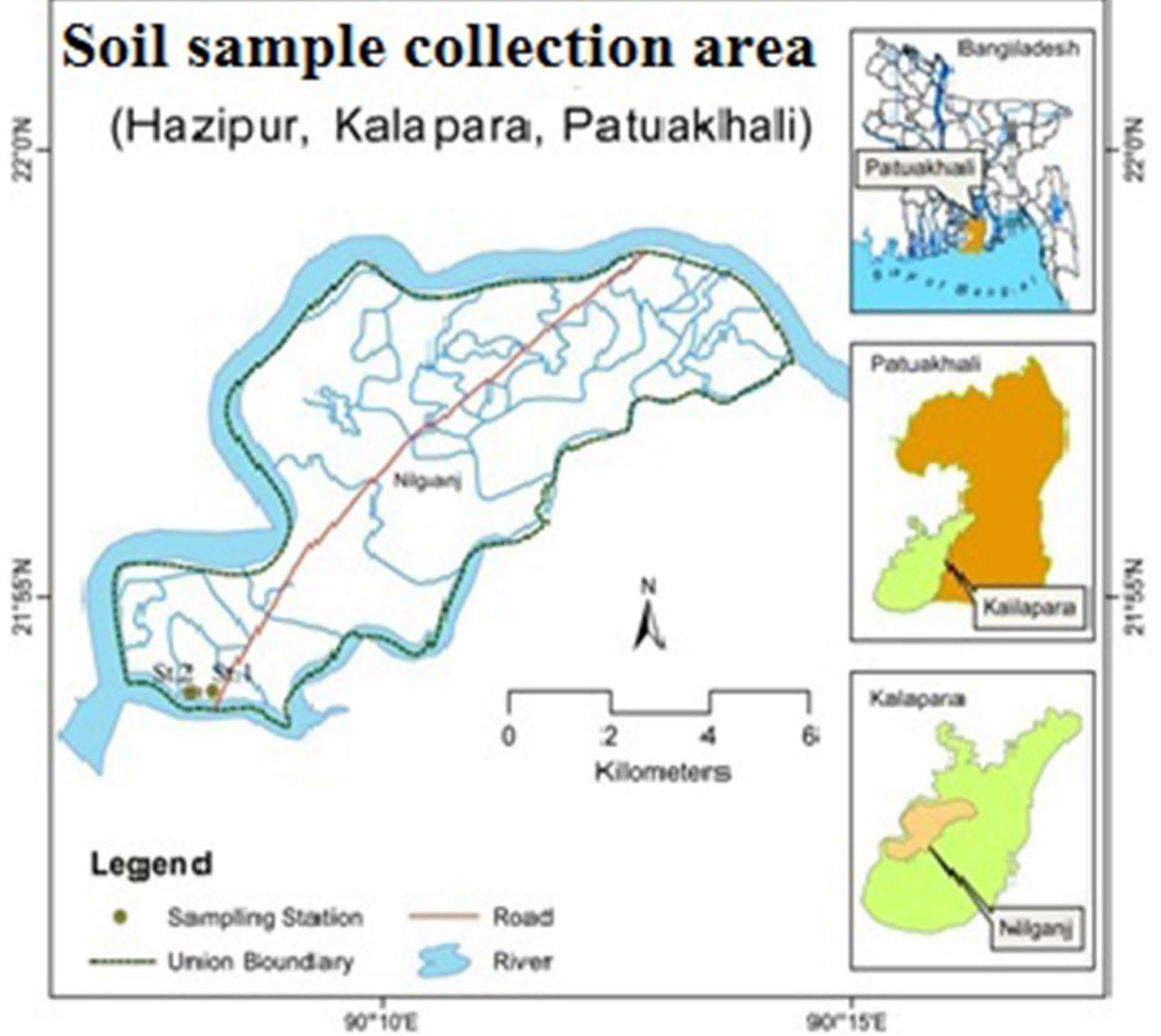

Fig. 1 a Map of wastewater collection area. b Map of soil sample collection area of Patuakhali, Bangladesh. c Map of soil sample collection area, Portugal 


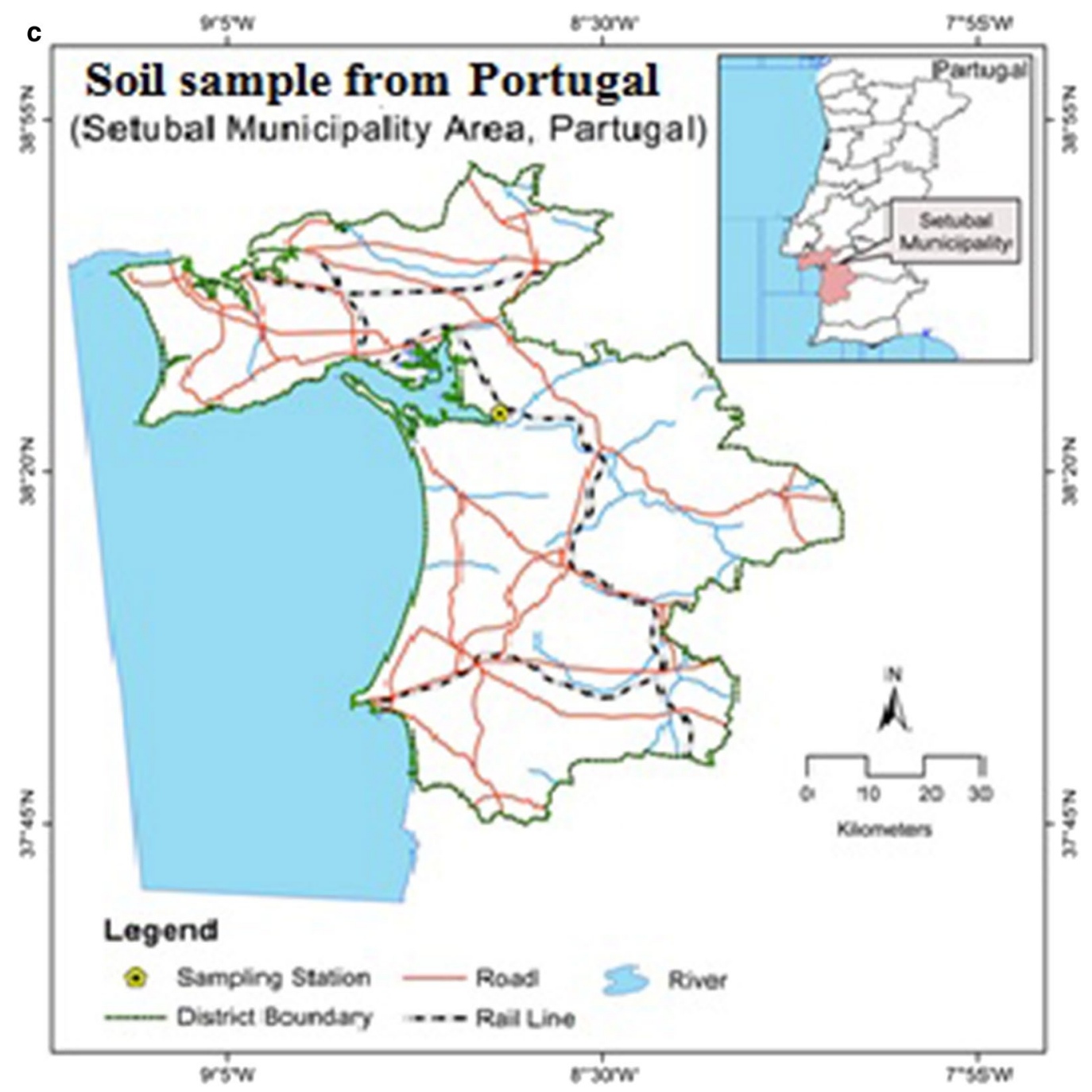

Fig. 1 (continued)

thermo-reactor for $2 \mathrm{~h}$ at $150^{\circ} \mathrm{C}$. Afterward, $200 \mathrm{ml}$ volume of waste water was selected for $1.5 \mathrm{gm}$ soil and $50 \mathrm{ml}$ was selected for $2.5 \mathrm{gm}$ soil.

\section{Removal efficiency}

The removal efficiency of turbidity, COD, and heavy metals was calculated according to the following formula:

Removal efficiency $(\%)=\frac{\left(C_{i}-C_{f}\right)}{C_{i}} \times 100$

where $C_{i}$ is the Initial concentration of the parameter and $\mathrm{C}_{\mathrm{f}}$ is the final concentration of the parameter.

\section{Statistical analysis}

Data were analyzed using software MS Excel for graphical presentation. Values were expressed as mean \pm SEM (standard error of mean). Correlation among the parameters has been done according to the Pearson correlation process in Statistical Package for Social Science (IBM SPSS Statistics 20.0).

\section{Results and discussion}

\section{Physicochemical parameters of the effluents}

Physicochemical properties of wastewater were determined before and after treatment with clay coagulants enable to predict the removal efficiency of clay coagulants. 


\section{Watercolor and odor}

The initial color of wastewater for all samples was dark violet to black. After the treatment, water from every sample was found nearly colorless and transparent. The odor of wastewater in all samples was observed pungent to high pungent. After treatment, the samples became odorless. The odor of freshwater samples was nearly odorless.

\section{Turbidity}

The primary mean values of turbidity were 50.14 NTU, 59.66 NTU, 252 NTU, 70.66 NTU, and 119.33 NTU found

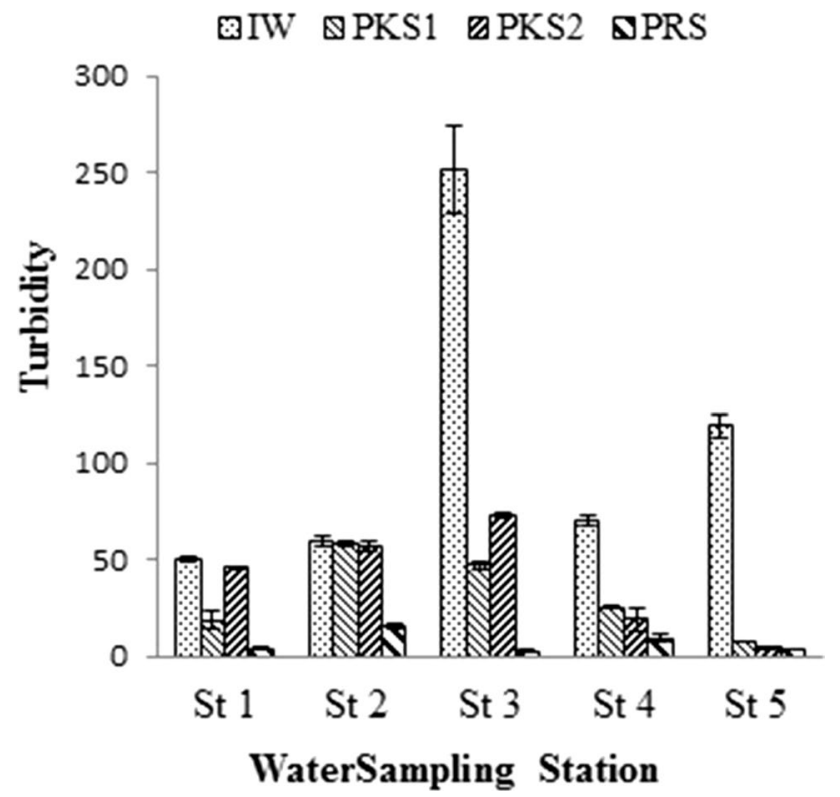

in stations 1,2,3,4, and 5, respectively (Fig. 2). When turbid samples were treated by clay from Patuakhali Clay sample-1(PKS-1), then the turbidity of wastewater from the station-1,2,3,4, and 5 decreased to 18.92 NTU, 58 NTU, 47.35 NTU, 25.62 NTU, and 7.70 NTU, respectively. After adding clay soil from Patuakhali clay sample-2(PKS-2), the turbidity decreased gradually to 45.86 NTU, 57 NTU, 73.33 NTU, 19.38 NTU, and 4.33NTU in station 1, 2, 3, 4, and 5, respectively. After adding clay from the Portugal clay sample (PRS), the turbidity decreased correlatively to 3.89 NTU, 15.43 NTU, 2.84 NTU, 9.27 NTU, and 3.77NTU in the water samples of station-1,2,3,4, and 5, respectively. It is revealed that the addition of clay coagulants can result in the reduction of turbidity in wastewater.

Turbidity removal efficiency obtained from PKS 01, PKS 02, and PRS was $77.44 \%, 63.77 \%$, and $93.62 \%$, respectively, to attain final turbidity $31.51 \mathrm{NTU}, 39.98 \mathrm{NTU}$, and 7.04 NTU, respectively (Table 1). The highest efficiency (93.62\%) was found for the Portugal clay sample (PRS). According to Awad et al. (2013), the removal efficiency for polyaluminum chloride (PAC) and its combined use with Shendi and Singa for turbidity was $96.2 \%, 94.8 \%$, and $95.7 \%$, which almost coincided with PRS of the present study. Kuipa et al. (2015) found Katonda clay in combination with alum for the treatment of surface water for drinking purposes with optimum turbidity removal of $89.9 \%$ at a dosage rate of $30 \mathrm{mg} / \mathrm{L}$ (30 mg/L Alum, $30 \mathrm{mg} / \mathrm{L}$ Clay). Saritha et al. (2017) showed that the removal of turbidity was up to $99 \%$ by both alum and chitin at lower doses of coagulant, i.e., $0.1-0.3 \mathrm{~g} / \mathrm{L}$, whereas sago has shown a reduction of $70-100 \%$ at doses of 0.1 and $0.2 \mathrm{~g} / \mathrm{L}$. However, using only natural clay coagulant, the present study gained the removal efficiency of $77.44 \%$ for PKS-1, 63.77\% for PKS-2 at doses of $1.5 \mathrm{~g} / \mathrm{L}$, and $93.62 \%$ for PRS at doses of $2.5 \mathrm{~g} / \mathrm{L}$.

Fig. 2 Turbidity of water before and after treatment

Table 1 Average value and removal efficiency (\%) of clay coagulant

\begin{tabular}{|c|c|c|c|c|c|}
\hline Parameters & & Initial & PKS 01 & PKS 02 & PRS \\
\hline \multirow[t]{2}{*}{ Turbidity } & Average value & 110.35 & 31.51 & 39.98 & 7.04 \\
\hline & Removal efficiency (\%) & & 77.44 & 63.77 & 93.62 \\
\hline \multirow[t]{2}{*}{$\mathrm{pH}$} & Average value & 9.487 & 8.34 & 8.37 & 7.82 \\
\hline & Removal efficiency (\%) & & 12.02 & 11.71 & 17.52 \\
\hline \multirow[t]{2}{*}{ COD } & Average Value & 745.53 & 417.56 & 397.18 & 469.14 \\
\hline & Removal efficiency (\%) & & 43.99 & 46.72 & 37.07 \\
\hline \multirow[t]{2}{*}{ Chromium $(\mathrm{Cr})$} & Average value & 93.14 & 13.68 & 8.88 & 9.84 \\
\hline & Removal efficiency (\%) & & 85.30 & 90.49 & 89.42 \\
\hline \multirow[t]{2}{*}{ Cadmium (Cd) } & Average value & 1.78 & 1.04 & 1.55 & 1.61 \\
\hline & Removal efficiency (\%) & & 41.59 & 12.59 & 9.21 \\
\hline \multirow[t]{2}{*}{ Lead $(\mathrm{Pb})$} & Average value & 208.52 & BDL & 1.09 & 8.69 \\
\hline & Removal efficiency (\%) & & N/A & 99.47 & 95.82 \\
\hline \multirow[t]{2}{*}{ Nickel (Ni) } & Average value & 67.98 & 38.85 & 43.89 & 66.72 \\
\hline & Removal efficiency (\%) & & 42.85 & 35.43 & 1.85 \\
\hline
\end{tabular}




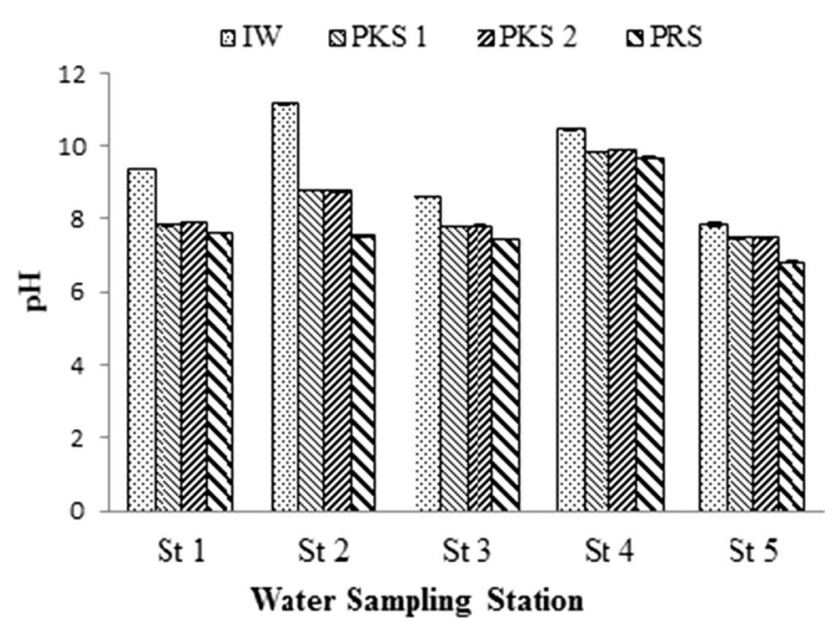

Fig. $3 \mathrm{pH}$ of wastewater before and after treatment

$\mathrm{pH}$

The initial mean $\mathrm{pH}$ in station-1,2,3,4, and 5 was 9.36, 11.15, 8.61,10.46, and 7.85, respectively (Fig. 3). After treating with the clay coagulant from PKS-1, the $\mathrm{pH}$ decreased to 7.84 (station-1), 8.80 (station-2), 37.78 (station-4), and 9.8 (station-5). When clay coagulant of PKS-2 was used for treatment, the $\mathrm{pH}$ was reduced to $7.91,8.77,7.82,9.89$, and 7.48 in the station $1,2,3,4$, and 5 , respectively, while using clay of PRS, the $\mathrm{pH}$ became 7.62, 7.54, 7.45, 9.68, and 6.81 in station-1,2,3,4, and 5, respectively.

However, the $\mathrm{pH}$ of the effluents was always higher when those were discharged from the industry. It might be due to the presence of alkaline wastes in industrial effluents. Here it is found that in all stations the $\mathrm{pH}$ has been decreased after adding clay soils as coagulants. Roy et al. (2010) used Saccostrea cucullata and Pistia stratiotes as a natural coagulant which reduced $\mathrm{pH} 22.50 \%$ and $22.18 \%$, respectively. In the present study for use of soil coagulant the reduction efficiency of $\mathrm{pH}$ was $12.02 \%, 11.71 \%$, and $17.52 \%$ from PKS 1, PKS 2, and PRS to attain final $\mathrm{pH} \mathrm{8.34,} \mathrm{8.37,} \mathrm{and} 7.82$ (Table 1), respectively, where the highest efficiency was found for PRS. The national standard of $\mathrm{pH}$ for the industrial units in Bangladesh is 6-9 (DoE 2008). The achieved result for $\mathrm{pH}$ after treatment remains within the standard.

\section{Chemical oxygen demand (COD)}

At the preliminary stage, the COD of the raw samples was 609.85 ppm, 736.23 ppm, 611.88 ppm, 1183.38 ppm, and $586.49 \mathrm{ppm}$ found in station $1,2,3,4$, and 5, respectively (Fig. 4). After treating with clay from PKS-1, the COD significantly reduced to $376.30 \mathrm{ppm}, 616.53 \mathrm{ppm}, 139.40 \mathrm{ppm}$, 746 ppm, and 209.57 ppm for station 1,2,3,4, and 5, respectively. Treating by clay from PKS-2, the COD decreased to

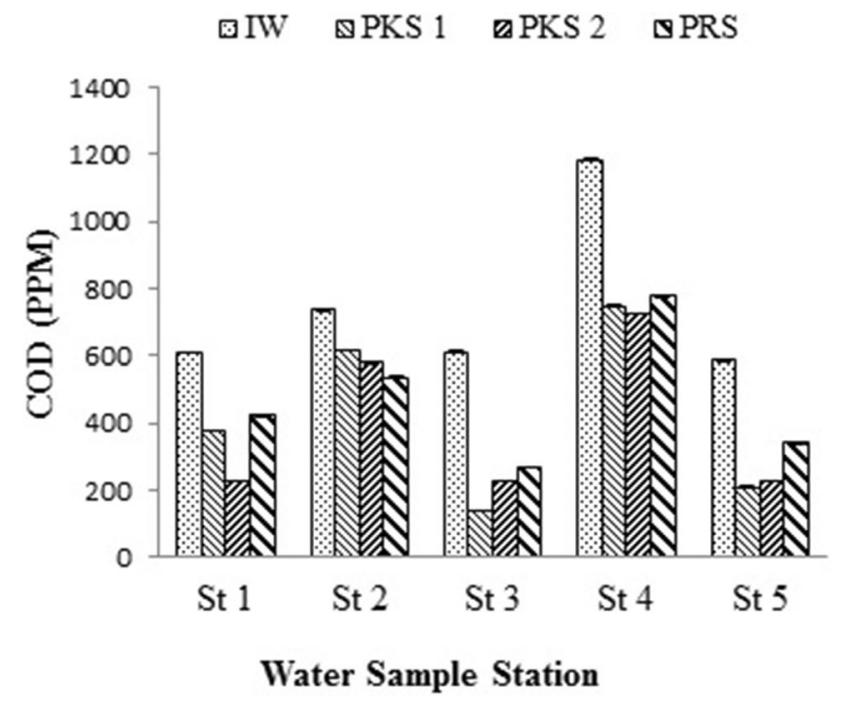

Fig. 4 COD of wastewater before and after treatment

225.35 ppm, 578.94 ppm, 229.62 ppm, 724.53 ppm, and 227.45 ppm that are place $d$ in station $1,2,3,4$, and 5 sequentially. After using clay from PRS, the concentration of COD values in station $1,2,3,4$, and 5 is $422.18 \mathrm{ppm}, 536.07 \mathrm{ppm}$, 269.66 ppm, $777.06 \mathrm{ppm}$, and $340.74 \mathrm{ppm}$, respectively. The standard value of suggested effluent discharge is $200 \mathrm{ppm}$ (DoE 2008). The yield value after treatment was almost to the standard level. Though all the treated wastewater was not within the standard limit of DoE (2008), still these were lower than the raw wastewater. Based on Pearson correlation analysis between PKS-1 dosed wastewater and PKS-1 soil properties, a strong positive correlation was found between COD and $\mathrm{pH}(r=0.93, p<0.05)$ and COD and $\mathrm{Fe}(r=0.93$, $p<0.05$ ) (Table 2). Similarly, a correlation was found between PKS-2 dosed wastewater and PKS-2 soil properties, as well as PRS, dosed wastewater, and PRS soil properties; a strong positive correlation was found between COD and $\mathrm{pH}(r=0.96, p<0.01)$ (Table 3$)$ and $(r=0.88, p<0.01)$ (Table 4), respectively.

Shah et al. (2015) found in a treatment that coagulant of $\mathrm{FeSO}_{4}$ lime influenced $32 \%$ reduction of COD, whereas the removal efficiencies obtained from the present study are more than that of the findings of Husain et al. (2013), who showed that the physicochemical method of coagulation and flocculation using alum with clay produced $92 \%$ COD removal where using soil without any chemical in this study has achieved $43.99 \%, 46.72 \%$, and $37.07 \%$ COD removal efficiency for PKS 01, PKS 02, and PRS, respectively (Table 1). Though Awad et al. (2013) found better removal efficiency for polyaluminum chloride (PAC) and its combined use with Shendi and Singa for COD, which were $70.7 \%, 63.2 \%$, and $61.1 \%$. It is revealed that the quality of treated effluent using PKS-1 and PKS-2 clay coagulants is 
Table 2 Correlation analysis for clay coagulant PKS-1

\begin{tabular}{llllllllllll}
\hline & $\mathrm{pH}$ & Turbidity & $\mathrm{COD}$ & $\mathrm{Cd}$ & $\mathrm{Cr}$ & $\mathrm{Ni}$ & $\mathrm{Pb}$ & $\mathrm{Al}$ & $\mathrm{Fe}$ & $\mathrm{Cl}^{-}$ & $\mathrm{SO}_{4}{ }^{2-}$ \\
\hline $\mathrm{pH}$ & 1 & & & & & & & & & & \\
Turbidity & 0.26 & 1 & & & & & & & & & \\
$\mathrm{COD}$ & $\mathbf{0 . 9 3} *$ & 0.20 & 1 & & & & & & & & \\
$\mathrm{Cd}$ & 0.85 & -0.15 & 0.70 & 1 & & & & & & & \\
$\mathrm{Cr}$ & -0.01 & 0.05 & 0.33 & -0.33 & 1 & & & & & & \\
$\mathrm{Ni}$ & $\mathbf{0 . 8 8}$ & -0.12 & 0.74 & $\mathbf{0 . 9 9 * *}$ & -0.30 & 1 & & & & & \\
$\mathrm{~Pb}$ &. $\mathrm{~b}$ &. $\mathrm{~b}$ &. $\mathrm{~b}$ &. $\mathrm{~b}$ &. $\mathrm{~b}$ &. $\mathrm{~b}$ &. $\mathrm{~b}$ & & & & \\
$\mathrm{Al}$ & .0 .56 & 0.70 & 0.59 & 0.19 & 0.38 & 0.22 &. $\mathrm{~b}$ & 1 & & & \\
$\mathrm{Fe}$ & 0.79 & -0.04 & $\mathbf{0 . 9 3} *$ & 0.65 & 0.49 & 0.67 &. $\mathrm{~b}$ & 0.54 & 1 & & \\
$\mathrm{Cl}^{-}$ & 0.51 & 0.43 & 0.52 & 0.22 & 0.04 & 0.27 &. $\mathrm{~b}$ & 0.09 & 0.23 & 1 & \\
$\mathrm{SO}_{4}{ }^{2-}$ & $\mathbf{0 . 9 1 *}$ & 0.58 & 0.77 & 0.69 & -0.17 & 0.72 &. $\mathrm{~b}$ & 0.63 & 0.53 & 0.61 & 1 \\
\hline
\end{tabular}

*Correlation is significant at 0.05 level (2-tailed)

**Correlation is significant at 0.01 level (2-tailed)

${ }^{\mathrm{b}} \mathrm{Cannot}$ be computed because at least one of the variables is constant

\begin{tabular}{llllllllllll}
\hline & $\mathrm{pH}$ & Turbidity & $\mathrm{COD}$ & $\mathrm{Cd}$ & $\mathrm{Cr}$ & $\mathrm{Ni}$ & $\mathrm{Pb}$ & $\mathrm{Al}$ & $\mathrm{Fe}$ & $\mathrm{Cl}^{-}$ & $\mathrm{SO}_{4}{ }^{2-}$ \\
\hline $\mathrm{pH}$ & 1 & & & & & & & & & \\
Turbidity & -0.12 & 1 & & & & & & & & & \\
$\mathrm{COD}$ & $\mathbf{0 . 9 6 * *}$ & -0.15 & 1 & & & & & & & & \\
$\mathrm{Cd}$ & 0.87 & -0.41 & 0.76 & 1 & & & & & & & \\
$\mathrm{Cr}$ & 0.33 & -0.14 & 0.33 & 0.10 & 1 & & & & & & \\
$\mathrm{Ni}$ & $\mathbf{0 . 8 9 *}$ & -0.37 & 0.80 & $\mathbf{0 . 9 9} * *$ & 0.11 & 1 & & & & & \\
$\mathrm{~Pb}$ & 0.22 & 0.34 & 0.42 & -0.25 & 0.36 & -0.19 & 1 & & & & \\
$\mathrm{Al}$ & -0.10 & -0.20 & 0.07 & -0.39 & 0.67 & $0-.37$ & 0.67 & 1 & & & \\
$\mathrm{Fe}$ & -0.71 & 0.63 & -0.74 & -0.84 & 0.09 & -0.84 & 0.07 & 0.17 & 1 & & \\
$\mathrm{Cl}^{-}$ & 0.72 & -0.52 & 0.74 & 0.62 & 0.78 & 0.63 & 0.25 & 0.45 & -0.55 & 1 \\
$\mathrm{SO}_{4}{ }^{2-}$ & 0.54 & 0.12 & 0.35 & 0.72 & -0.36 & 0.72 & -0.48 & $\mathbf{- 0 . 8 8 *}$ & -0.43 & -0.02 & 1 \\
\hline
\end{tabular}

*Correlation is significant at 0.05 level (2-tailed)

***Correlation is significant at 0.01 level (2-tailed)

\begin{tabular}{llllllllllll}
\hline & $\mathrm{pH}$ & Turbidity & $\mathrm{COD}$ & $\mathrm{Cd}$ & $\mathrm{Cr}$ & $\mathrm{Ni}$ & $\mathrm{Pb}$ & $\mathrm{Al}$ & $\mathrm{Fe}$ & $\mathrm{Cl}^{-}$ & $\mathrm{SO}_{4}{ }^{2-}$ \\
\hline $\mathrm{pH}$ & 1 & & & & & & & & & & \\
Turbidity & 0.31 & 1 & & & & & & & & & \\
$\mathrm{COD}$ & $\mathbf{0 . 8 8}$ & 0.62 & 1 & & & & & & & & \\
$\mathrm{Cd}$ & $\mathbf{0 . 9 5}^{*}$ & 0.23 & 0.86 & 1 & & & & & & & \\
$\mathrm{Cr}$ & -0.10 & 0.73 & 0.32 & -0.18 & 1 & & & & & & \\
$\mathrm{Ni}$ & $\mathbf{0 . 9 4}^{*}$ & 0.57 & $\mathbf{0 . 9 8 * *}$ & $\mathbf{0 . 9 1 *}$ & 0.18 & 1 & & & & & \\
$\mathrm{~Pb}$ & $\mathbf{0 . 9 5}^{*}$ & 0.23 & 0.86 & $\mathbf{0 . 9 8 * *}$ & -0.18 & $\mathbf{0 . 9 1 *}$ & 1 & & & & \\
$\mathrm{Al}$ & -0.15 & -0.68 & -0.52 & -0.30 & -0.53 & -0.43 & -0.30 & 1 & & & \\
$\mathrm{Fe}$ & 0.76 & -0.64 & -0.74 & -0.72 & 0.01 & -0.80 & -0.72 & 0.41 & 1 & & \\
$\mathrm{Cl}^{-}$ & 0.32 & -0.42 & -0.10 & 0.15 & -0.63 & 0.02 & 0.15 & 0.84 & -0.13 & 1 & \\
$\mathrm{SO}_{4}{ }^{2-}$ & 0.50 & -0.20 & 0.26 & 0.66 & -0.71 & 0.36 & 0.66 & -0.15 & -0.52 & 0.19 & 1 \\
\hline
\end{tabular}

*Correlation is significant at 0.05 level (2-tailed)

***Correlation is significant at 0.01 level (2-tailed)
Table 4 Correlation analysis for clay coagulant PRS
Table 3 Correlation analysis for clay coagulant PKS-2 
quite satisfactory. These results indicate that clay coagulants used in the present study would be efficient for the removal of COD from such wastewater.

\section{Chromium (Cr)}

The optimum concentration of chromium $(\mathrm{Cr})$ for GFAAS machine ranges from 5 to $100 \mathrm{ppb}$. The elementary concentration of $\mathrm{Cr}$ in effluents for station-1 was $112.98 \mathrm{ppb}$, for station-2 it was $95.62 \mathrm{ppb}$, for station-3 it was $39.122 \mathrm{ppb}$, for station-4 was $25.923 \mathrm{ppb}$, and for station-5 it was 192.09 ppb (Fig. 5). But after treating with clay from PKS1 , the concentration of $\mathrm{Cr}$ decreased to $25.70 \mathrm{ppb}, 25.32 \mathrm{ppb}$, $6.77 \mathrm{ppb}$, and $10.62 \mathrm{ppb}$ for station-1,2,4, and 5, respectively, and in treatment by clay soil of PKS-2, the concentration of Cr reduced for station-1 (15.63 ppb) for station-2, 4, and 5 (12.83 ppb, $10.06 \mathrm{ppb}$, and $5.76 \mathrm{ppb}$, respectively), whereas after treatment by PRS clay sample, the concentration of Cr reduced for station-1 (12.6 ppb), station-2, 4, and 5 (20.01 ppb, 7.48 ppb, and 9.13 ppb, respectively). Mahmood et al. (2005) used Eichhornia crassipies for wastewater treatment and recorded $78.30 \%$ to $94.78 \%$ reduction where the present study provides $85.3 \%, 90.49 \%$, and $89.42 \%$ removal for PKS 1, PKS 2 and PRS (Table 1). According to DoE (2008), the discharge limit of total $\mathrm{Cr}$ (as Cr molecule) in a classified textile industry is $2 \mathrm{mg} / \mathrm{L}$.

\section{Cadmium (Cd)}

The optimum concentration of cadmium (Cd) for GFAAS ranges from 0.5 to $10 \mathrm{ppb}$. The initial content of $\mathrm{Cd}$ in the effluent for station-1, 2, 3, and 5 is under outlier and for station-4 it is $8.896 \mathrm{ppb}$. After adding clay from PKS-1 and
PKS-2 and PRS, Cd's concentration for station-1, 2, 3, and 5 is under outlier and for station-4 it was $5.19 \mathrm{ppb}, 7.77 \mathrm{ppb}$, and $8.07 \mathrm{ppb}$, respectively (Fig. 6). The removal efficiencies for PKS-1, PKS-2, and PRS were found 41.59\%, $12.59 \%$, and $9.21 \%$, respectively (Table 1 ). The efficiency was high in PKS-1. Based on correlation analysis between PRS dosed wastewater and PRS soil properties, strong positive correlation was found between $\mathrm{Cd}$ and $\mathrm{pH}(r=0.95, p<0.01)$ (Table 4).

\section{Lead $(\mathrm{Pb})$}

The optimum concentration of lead $(\mathrm{Pb})$ for GFAAS ranged from 5 to $100 \mathrm{ppb}$. The primary concentration of lead ( $\mathrm{Pb}$ ) for station-1, 2, 3, 4, and 5 is $423.07 \mathrm{ppb}, 57.13 \mathrm{ppb}$, 167.25 ppb, 130.33 ppb, and 264.83 ppb gradually (Fig. 7). After using clay from PKS-1, the concentration of lead $(\mathrm{Pb})$ is under outlier for all the wastewater samples and using clay from PKS-2 and PRS, the concentrations of lead $(\mathrm{Pb})$ for wastewater sample station-1, 2, 3, and 5 are below detection and for station-4, it is $5.49 \mathrm{ppb}$ and $43.49 \mathrm{ppb}$, respectively. The removal efficiency for PKS-1 is not detected, but for PKS-2 and PRS is $99.47 \%$ and $95.82 \%$ (Table 1). Based on correlation analysis between PRS dosed wastewater and PRS soil properties, strong positive correlation was found between $\mathrm{Pb}$ and $\mathrm{pH}(r=0.95, p<0.01), \mathrm{Pb}$ and $\mathrm{Cd}(r=0.98$, $p<0.01)$, and $\mathrm{Pb}$ and $\mathrm{Ni}(r=0.91, p<0.01)$ (Table 4$)$. In this aspect, the efficiency is high in PKS-2. Tiruneh et al. (2018) observed high percentage removal of lead which was ranging from 98.84 to $99.69 \%$ by using aluminum sulfate with clay.

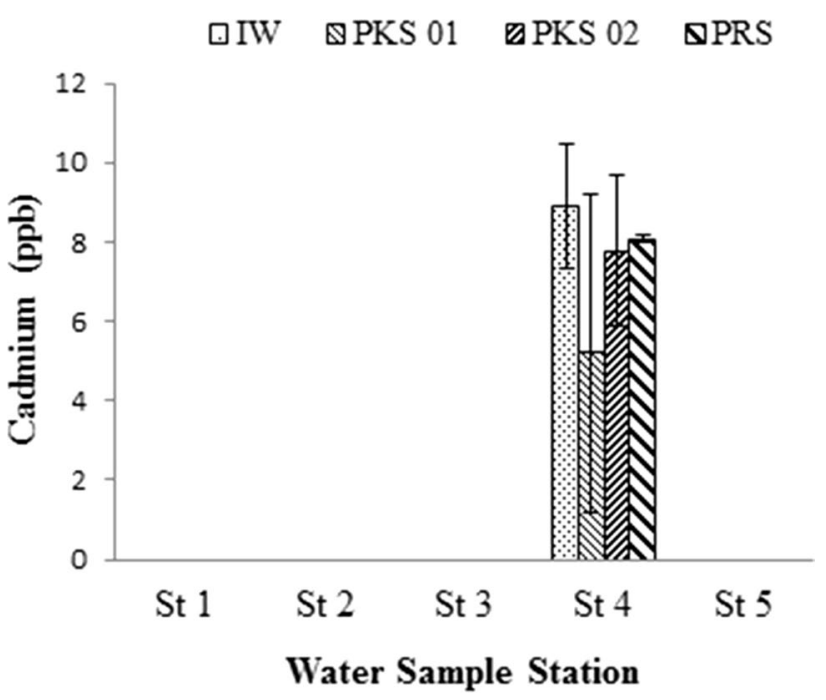

Fig. $6 \mathrm{Cd}$ concentration before and after treatment
Fig. $5 \mathrm{Cr}$ concentration before and after treatment

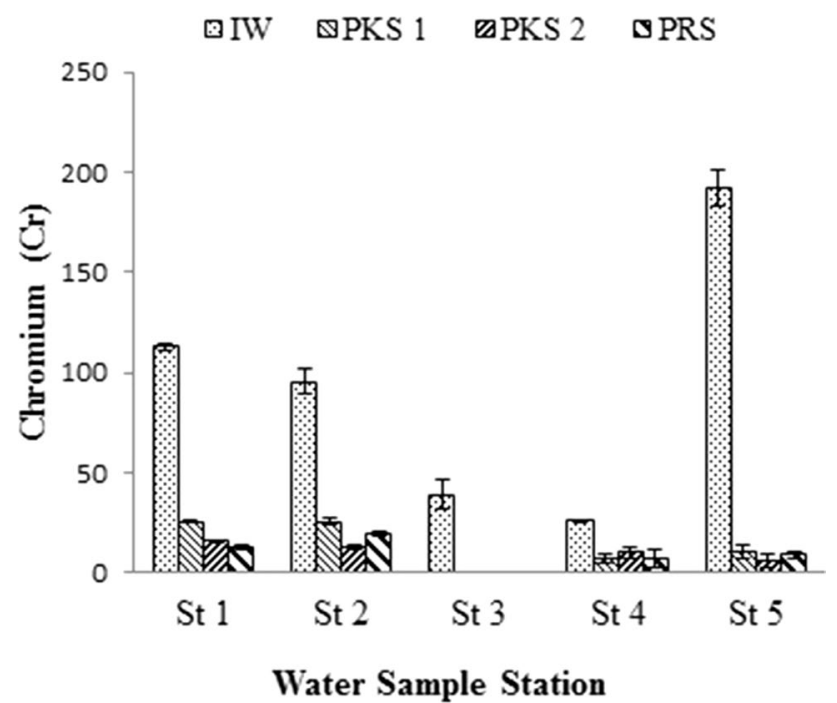




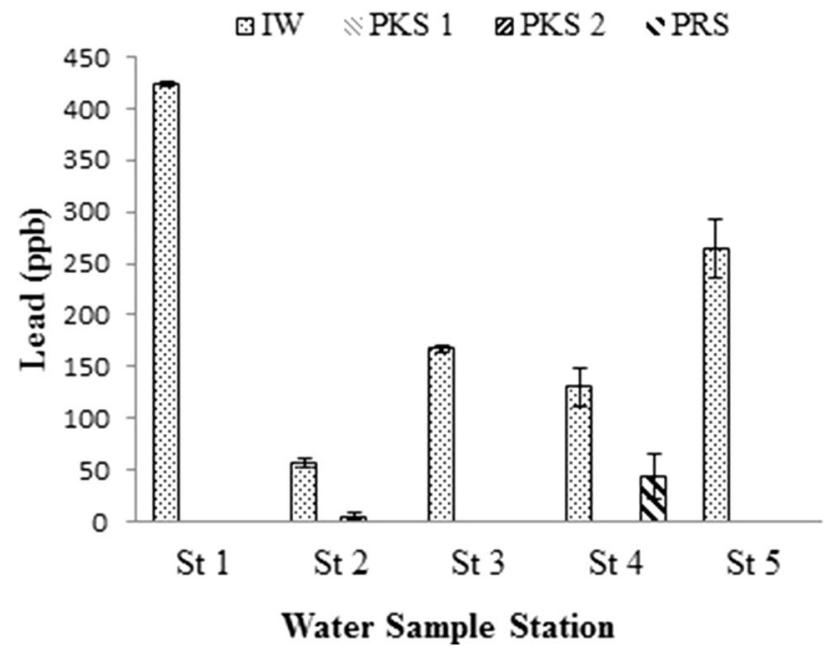

Fig. $7 \mathrm{~Pb}$ concentration before and after treatment

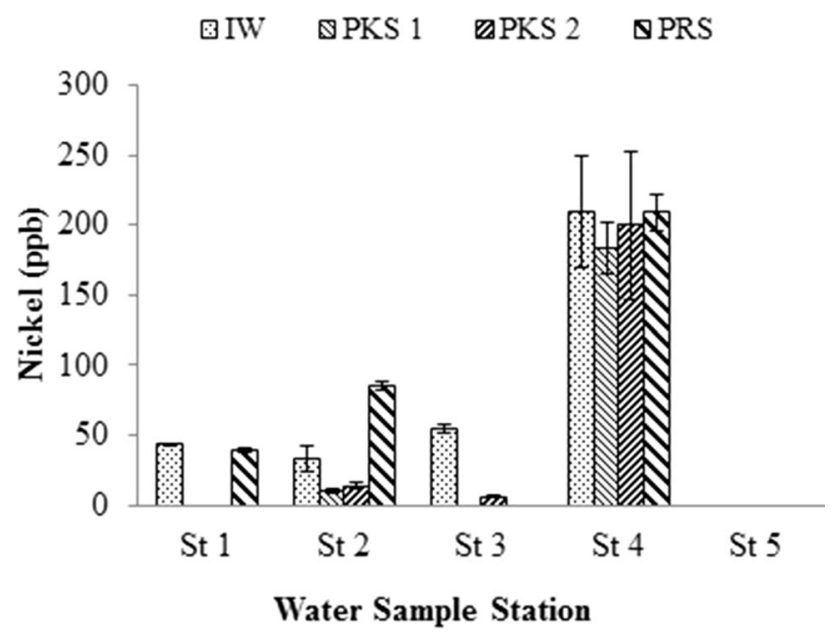

Fig. $8 \mathrm{Ni}$ concentration before and after treatment

\section{Nickel (Ni)}

The optimum concentration of nickel (Ni) for GFAAS ranges from 5 to $100 \mathrm{ppb}$. The initial concentration of $\mathrm{Ni}$ in station-1,2,3, and 4 is 43.08 ppb, 33.19 ppb, $54.07 \mathrm{ppb}$, and $209.58 \mathrm{ppb}$ (Fig. 8). Using clay soil from PKS-1, the concentration of nickel (Ni) for water sample station-1, 3, and 5 is not detected and for station-2 and 4, these are $10.34 \mathrm{ppb}$ and $183.91 \mathrm{ppm}$, respectively, whereas using soil from PKS-2, the concentration of nickel (Ni) for station- 1 and 5 is below detection and for station-2,3, and 4, these are $13.64 \mathrm{ppb}$ and $5.99 \mathrm{ppb}$ and $199.82 \mathrm{ppb}$, respectively. Adding clay soil from PRS, the concentration of nickel (Ni) for station-3 and 5 is an outlier and for station-1, 2, and 4, those are $38.96 \mathrm{ppb}$, $85.33 \mathrm{ppb}$, and $209.33 \mathrm{ppb}$ gradually. The standard limit of $\mathrm{Ni}$ in surface water of Bangladesh is $1.0 \mathrm{ppm}$ (DoE 2008).
Based on Pearson correlation analysis between PKS 01 dosed wastewater and PKS-1 soil, a strong positive correlation was found between $\mathrm{Ni}$ and $\mathrm{pH}(r=0.88, p<0.05)$ and $\mathrm{Ni}$ and $\mathrm{Cd}(r=0.99, p<0.01)$ (Table 2), and between PKS-2 dosed wastewater and PKS-2 soil properties a strong positive correlation was found between $\mathrm{Ni}$ and $\mathrm{Cd}(r=0.99$, $p<0.01$ ) (Table 3) and $\mathrm{Ni}$ and $\mathrm{pH}(r=0.89, p<0.05)$, and between PRS dosed wastewater and PRS soil properties a strong positive correlation was found between $\mathrm{Ni}$ and $\mathrm{pH}$ $(r=0.94, p<0.01), \mathrm{Ni}$ and COD $(r=0.98, p<0.01)$, and $\mathrm{Ni}$ and $\mathrm{Cd}(r=0.91, p<0.01)$ (Table 4$)$.

Esmaeili et al. (2019) observed the removal efficiency of $\mathrm{Ni}$ by bentonite at dose $60 \mathrm{~g} / \mathrm{l}$ was $99.9 \%$. The removal efficiencies for PKS-1, PKS-2, and PRS were $42.85 \%, 35.43 \%$, and $1.85 \%$, respectively (Table 1 ). The efficiency was high (42.85\%) in PKS-1 and very poor in PRS.

It is revealed from experimental analysis in some cases, physicochemical parameters (such as color, odor, $\mathrm{pH}$, turbidity, $\mathrm{COD}$ ) and heavy metals (like $\mathrm{Cr}, \mathrm{Cd}, \mathrm{Pb}$, and $\mathrm{Ni}$ ) of industrial wastewater were higher than that of the recommended value set by DoE (2008) and ECR (1997).

Results for the treatment with clay coagulants show significant efficiency in most of the cases. In this case, more pollutant removal efficiency was found for local clay (PKS1, PKS2). However, some previous researchers found better efficiency using different coagulants for pollutant removal.

\section{Conclusion}

The study revealed the potentiality and effectiveness of natural clay as a coagulant in the removal of pollutants from wastewater. Clay coagulants have been shown the ability in the removal of pollutants for the gainful application. In this study, the industrial wastewater was treated with clay collected from Portugal and Patuakhali coastal area of Bangladesh to investigate its efficiency in reducing $\mathrm{pH}, \mathrm{COD}$, and heavy metals including $\mathrm{Cd}, \mathrm{Cr}, \mathrm{Ni}$, and $\mathrm{Pb}$. The removal efficiencies for turbidity, $\mathrm{pH}, \mathrm{COD}, \mathrm{Cd}, \mathrm{Cr}$, $\mathrm{Ni}$, and $\mathrm{Pb}$ are $77.44 \%, 12.02 \%, 43.99 \%, 41.59 \%, 85.30 \%$, and $42.85 \%$ for Patuakhali clay-1; 63.77\%, 11.71\%, 46.72\%, $12.59 \%, 90.49 \%, 35.43 \%$, and $99.47 \%$ for Patuakhali clay-2; and $93.62 \%, 17.52 \%, 37.07 \%, 9.21 \%, 89.42 \%, 1.85 \%$, and $95.82 \%$ for Portugal clay, respectively.

The technology of using soil for the treatment of industrial wastewater is an alternative method to the conventional methods available. It is more cost-effective for us. The result is satisfactory for our native local soil than foreign soil, and moreover, local soil is available and easy to collect. Furthermore, research should be performed to determine the removal efficiency of biological contaminants and other heavy metals of wastewater utilizing soil. Beside these, a wide variety of soils need to be examined to find out prominent coagulants for wastewater treatment.

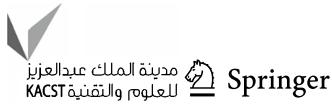


Acknowledgements The authors acknowledge the cooperation of the Department of Environmental Science and Resource Management (ESRM), Mawlana Bhashani Science and Technology University (MBSTU), and Bangladesh Reference Institute for Chemical Measurements (BRiCM), Bangladesh Council of Scientific and Industrial Research (BCSIR) for the laboratory facilities.

Funding The author(s) received no specific funding for this work.

\section{Declarations}

Conflict of interest There is no conflict of interest regarding this manuscript.

Ethical approval Authors firmly abide by all ethical norms and follow the guidelines set by COPE.

Open Access This article is licensed under a Creative Commons Attribution 4.0 International License, which permits use, sharing, adaptation, distribution and reproduction in any medium or format, as long as you give appropriate credit to the original author(s) and the source, provide a link to the Creative Commons licence, and indicate if changes were made. The images or other third party material in this article are included in the article's Creative Commons licence, unless indicated otherwise in a credit line to the material. If material is not included in the article's Creative Commons licence and your intended use is not permitted by statutory regulation or exceeds the permitted use, you will need to obtain permission directly from the copyright holder. To view a copy of this licence, visit http://creativeco mmons.org/licenses/by/4.0/.

\section{References}

Abdelaal AM (2004) Using a natural coagulant for treating wastewater. In: $8^{\text {th }}$ International Water Technology Conference (IWTC8), Alexandria, Egypt, 781-791

APHA-American Public Health Association (1995) Standard methods for the examination of water and wastewater $19^{\text {th }}$ edition. Washington DC

Awad M, Li F, Hongtao W (2013) Application of natural clays and poly aluminium chloride (PAC) for wastewater treatment. Int J Recent Res Appl Stud 15(2):287-291

Cadena F, Rizvi R, Peters RW (1990) Feasibility studies for the removal of heavy metals from solution using tailored bentonite. In: Hazardous and industrial wastes- proceedings of the Mid-Atlantic Industrial Waste Conference, Drexel University, 77-94

DoE- Department of Environment (2008) Guideline for assessment of effluent treatment plant in EMP/EIA reports for textile industries. Ministry of Environment and Forest, Bangladesh, $1^{\text {st }}$ Edition, June 2008

DPCD-Diffuse Pollution Conference Dublin (2003) Aquatic ecology and dangerous substances: Bangladesh perspective Institution for Environment and Development Studies. 8CEco 8-65

ECR (1997) The environment conservation rules 1997. Available at https://www.elaw.org/system/files/Bangladesh+--+Environmen tal+Conservation+Rules, + 1997.pdf

Esmaeili A, Mobini M, Eslami H (2019) Removal of heavy metals from acid mine drainage by native natural clay minerals, batch and continuous studies. Appl Water Sci 9(4):97

Gillott JE (1968) Clay in engineering geology. Elsevier

Hajjaji M, Kacim S, Alami A, El Bouadili A, El Mountassir M (2001) Chemical and mineralogical characterization of a clay taken from the Moroccan Meseta and a study of the interaction between its fine fraction and methylene blue. App ClaSci 20(1-2):1-12
Hascakir B, Dolgen D (2008) Utilization of clay minerals in wastewater treatment: organic matter removal with kaolinite. Ekoloji 17(66):47-54

Husain A, Saini P, Javed I (2013) Physicochemical treatment of textile mill dye waste by coagulation and flocculation using alum with bentonite clay. J Chemand Pharm Res 5(2):70-73

Ingram DS, Vince-Prue D, Gregory PJ (2003) Science and the garden: the scientific basis of horticultural practice. Blackwell Science Ltd., Oxford

Judd S (1999) Industry's reuse challenge. Water 21:48-49

Kuipa O, Kuipa PK, Mangunda CT, Mwanza W (2015) Evaluation of Zimbabwean Katondo clay as a coagulant aid for treating low turbidity surface water with alum. Int J Chem Environ Eng 6(4):219-222

Laird DA, Fleming PD (1999) Mechanisms for adsorption of organic bases on hydrated smectite surfaces. Environ Toxic Chem 18(8):1668-1672

Mahmood Q, Zheng P, Islam E, Hayat Y, Hassan MJ, Jilani G, Jin RC (2005) Lab-scale studies on water hyacinth (Eichhornia crassipes Marts Solms) for biotreatment of textile wastewater. Casp J Environ Sci 3(2):83-88

Mohamed RMSR, Gheethi AA, Kassim AHBM (2017) Application of natural coagulants for wastewater treatment. Integrated Water Resource Management

Riera-Torres M, Gutiérrez-Bouzán C, Crespi M (2010) Combination of coagulation-flocculation and nanofiltration techniques for dye removal and water reuse in textile effluents. Desalination 252(1-3):53-59

Roy R, Fakhruddin ANM, Khatun R, Islam MS (2010) Reduction of COD and $\mathrm{pH}$ of textile industrial effluents by aquatic macrophytes and algae. J Bangladesh Acad Sci 34(1):9-14

Sanchez JM, Beltran JH, Peres JA (2012) Improvement of the flocculation process in water treatment by using Moringa oleifera seeds extract. Braz J Chem Eng 29(3):495-502

Saritha V, Srinivas N, Vuppala NS (2017) Analysis and optimization of coagulation and flocculation process. App Wat Sci 7(1):451-460

Schulthess CP, Huang CP (1990) Adsorption of heavy metals by silicon and aluminium oxide surfaces on clay minerals. Soil Sci Soc Am J 54(3):679-688

Shah SFA, Aftab A, Soomro N, Nawaz MS, Vafai K (2015) Waste water treatment-bed of coal fly ash for dyes and pigments industry. Pak J Anal Environ Chem 16(2):48-56

Sharma YC, Gupta GS, Prasad G, Rupainwar DC (1990) Use of wollastonitein the removal of $\mathrm{Ni}$ (II) from aqueous solutions. Water Air Soil Pollut 49(1-2):69-79

Sultana MS, Islam MS, Saha R, Mansur MAA (2009) Impact of the effluents of textile dyeing industries on the surface water quality inside D.N.D embankment, Narayanganj, Bangladesh. J Sci Indus Res 44(1):65-80

Tiruneh AT, Debessai TY, Bwembya GC, Nkambule SJ (2018) Combined clay adsorption-coagulation process for the removal of some heavy metals from water and wastewater. Am J Environ Eng 8(2):25-35

Verma AK, Dash RR, Bhunia P (2012) A review on chemical coagulation/ flocculation technologies for removal of colour from textile wastewaters. J Environ Manag 93(1):154-168

Viraraghavan T, Kapoor A (1994) Adsorption of mercury from wastewater by bentonite. Appl Clay Sci 9(1):31-49

Wu J, Laird DA, Thompson ML (1999) Sorption and desorption of copper on soil clay components. J Environ Qual 28(1):334-338

Yarahmadi M, Hosseini M, Bina B, Mahmoudian MH, Naimabadie A, Shahsavani A (2009) Application of Moringaoleifera seed extract and polyaluminum chloride in water treatment. World App Sci J 7(8):962-967

Publisher's Note Springer Nature remains neutral with regard to jurisdictional claims in published maps and institutional affiliations. 